\title{
Intercultural Theology and the challenge of the Indigenous Peoples in Latin America
}

\section{Roberto E. Zwetsch ${ }^{1}$}

\section{Introduction}

This text is part of a research project that I have been developing for several years in the Faculdades EST Graduate Program. In mid-2011 it was approved under the title of "Interculturality in Latin America". The title is very broad to cover different research studies that are being performed within the sphere of the Graduate Program and by researchers from other institutions with which we are in partnership. It deals with the fields of theology, philosophy, history, anthropology and related areas.

As regards the Exchange Program between Brazil and South Africa-PROAFRICA—, at the previous meetings I presented verbally, for debate, two other studies: 1) Theological Education and Interculturality. A Latin American Approach Based on the Manifesto for Quality Theological Education (São Leopoldo, Brazil, October 2009); 2) Theology and Interculturality in Latin America (Pretoria, South Africa, September 2011). The reflections that I am proposing in this third text on the topic of interculturality obviously take the previous lectures into account. But the purpose here is more specific. I intend to discuss the possibility of establishing an intercultural dialogue between the indigenous worldviews of the Amerindian peoples and Christian theology on the basis of the framework of the intercultural theology that is being elaborated. As a text for immediate reference I mention the essay that Rogério S. Link and I published under the title "Sitting in the Indigenous Hammock to Hear Better. Challenges of Indigenous Issues for Theology". ${ }^{2}$ I also refer more directly to the article that I wrote under the title "Deus na aldeia': A relação entre protagonismo indígena, ação missionária de igrejas cristãs e outros agentes em comunidades indígenas" ["God in the Village": The Relationship between Indigenous Protagonism, Missionary Action of Christian Churches and Other

$1 \mathrm{PhD}$ in Theology from Faculdades EST, professor of Missiology and Practical Theology at Faculdades EST, in São Leopoldo, RS, Brazil. He does research on the issue of Christian mission and cultures in Latin America. He has written books and articles on topics related to this field of research. His most important book is Missão como com-paixão. Por uma teologia da missão em perspectiva latinoamericana (São Leopoldo: Sinodal; Quito: CLAl, 2008).

2 Rogério S. Link and Roberto E. Zwetsch, "Sitting in the Indigenous Hammock to Hear Better. Challenges of Indigenous Issues for Theology”, in Public Theology in Brazil: Social and Cultural Challenge, ed. by Eneida Jacobsen, Rudolf von Sinner and Roberto E. Zwetsch (Münster: LIT, 2013), Theology in the Public Sphere vol. 6, 25-50. 
Agents in Indigenous Communities]. ${ }^{3}$ In this sense, the present text is the result of a broad collective reflection that we are developing in Brazil, in which several researchers are participating, as the list of references tries to show. Even so, the discussion presented here is entirely my responsibility.

\section{Framework of reference for an intercultural theology in Latin America}

In the paper presented in September 2011, I began my talk based on three assumptions: 1) A historical view of colonization and decolonization in Latin America; 2) The need to elaborate a definition (even if only provisional) of the concept of interculturality; 3) The intercultural paradigm as a challenge for theology in Latin America. In order to make the debate that I try to develop in this text easier, I will return to a few topics from that talk which may help us take a step forward:

As to the history of colonization and of the imposition of the Iberian culture on the peoples of the land in Latin America (a name given by the colonizers), I recalled that at least three forms were used by the colonizers to destroy the Amerindian cultures and impose the Iberian view: total denial of the culture of the other; imposition of the Iberian culture and assimilation of the other via symbolic cannibalism or syncretism; juxtaposition or segregation through reduction of the territory and tolerance of the existence of the different. As no political, economic or cultural domination is absolute, even after repeated genocides, indigenous resistance and the clamour of these peoples for life and rights were heard throughout history and implied changes in the relationship with them. In this context there emerged historical experiences of peaceful interaction with the indigenous peoples and the search for the affirmation of indigenous rights as human rights, not as individual rights but collective ones: the right to land, to cultural diversity (language, education), to their own religious worldview ${ }^{4}$.

- Understanding diversity as a cultural wealth against the colonizers' monoculture is situated in this context of resistance. Diversity as a value, and not as a barrier preventing life in society, is what leads to establishing intercultural relations that, ideally, tend to overcome the asymmetry of those societies by symmetrical and mutually satisfactory relationships.

3 Roberto E. Zwetsch, “'Deus na aldeia'. A relação entre protagonismo indígena, ação missionária de igrejas cristãs e outros agentes em comunidades indígenas", in Missões, militância indigenista e protagonismo indígena, edited by Protasio Paulo Langer and Graciela Chamorro (Dourados: UFGD; São Bernardo do Campo: Nhanduti, 2012), 39-55.

4 See Graciela Chamorro, "Indigenous Religions and Cultures: Apropos na Intercultural Public Theology", in Public Theology in Brazil: Social and Cultural Challenges, ed. by Eneida Jacobsen, Rudolf von Sinner and Roberto E. Zwetsch (Münster: LIT, 2013), Theology in the Public Square vol. 6, 7-24. 
- The intercultural paradigm whose general lines I am describing here is being debated by many researchers in Latin America. I have more systematically taken support from the texts of Raúl Fornet-Betancourt, a Cuban who teaches at the University of Aachen in Germany, and Josef Estermann, a Swiss who lived for over 20 years in Peru and Bolivia and developed research with the Andean peoples based on a good knowledge of the Quechua and Aymara languages. I take the following definition of interculturality from Fornet-Betancourt:

Interculturality intends to designate ... the attitude or disposition by which human beings are capable of living "their" identity references in relation to the socalled others, i.e. sharing them in interaction with the latter. Therefore it is an attitude that opens up human beings and drives them to a process of re-learning and contextual repositioning. ${ }^{5}$

For Estermann, before defining interculturality, it is important to make clear what it is not: interculturality is not multiculturalism (or pluriculturalism); supra- or metaculturalism; superculturalism or transculturalism. According to this author, although the phenomena above should be taken into account in the debate based on the historical reality in which we currently work, interculturality aims at reaching another level of relations and goals. Estermann defines interculturality as describing symmetrical and horizontal relations between two or more cultures, for the purpose of enriching each other and contributing to greater human fullness. ${ }^{6}$ Thus defined, interculturality goes beyond a mere coexistence between those who are different. Taking up the intercultural paradigm means to open oneself to those who are different, considering their own value, not to seek what is exotic about the others, but what creates mutual enrichment for both parties involved, such that there will be the possibility of a relationship of respect, learning and equity, in the sense of greater cultural justice and a mutually satisfactory life experience. It has to do, therefore, with the humanization of the human person and the recovery of their dignity. This involves the learning of the cultural dialogue, the deconstruction of colonial thinking that comprehends both philosophy and theology in Latin America, to finally create the conditions and the environment that enable experiencing the intercultural encounter and the construction of a paradigm, consequently the possibility of a critical and alternative intercultural theology.

5 Raúl Fornet-Betancourt, Interculturalidade. Crítica, diálogo e perspectivas (São Leopoldo: Nova Harmonia, 2004), 13.

6 See Josef Estermann, Interculturalidad. Vivir la diversidad (La Paz: ISEAT, 2010), 33.

7 For a discussion of the matter in its relationship to liberation theologies, see Roberto E. Zwetsch, "Teologias da libertação e interculturalidade: aproximações e avaliação crítica", Protestantismo em Revista, São Leopoldo, 30 (April-June 2013), 32-49. Available at: http://periodicos.est.edu.br/in- 


\section{Theology and Interculturality in Latin America}

Although the proposal for an intercultural theology has been elaborated in Europe since the mid-1970s, the critical intercultural paradigm was born in Latin America as a way to overcome the colonialism and neocolonialism imposed on the peoples of Africa, America, the Caribbean and Asia. It is articulated from different situations of poverty and non-life that affect millions of people on these continents, people and peoples that have never accepted oppression passively, but have raised a clamour that theology needs to hear, if indeed it pays attention to what the Spirit is telling the churches today.

To adopt the intercultural perspective in theological reflection means the achievement of symmetrical and liberating relations between subjects and societies. It implies overcoming androcentrism, ethnocentrism and the arrogance of Western science. $^{8}$ The central objective is the joint search for a completely new project of dialogue, or rather, of mutual conversation, that is relevant, committed and liberating for both parties, through a symbolic and political negotiation.

Against all types of a priori valid universal truths, it is accepted that truth and justice are only experienced in a common journey with one another, in which God reveals Godself as creator, liberator, and comforter, living and loving Trinity who calls to a full life with the other and not without the other's consentment.

As an essential requirement, taking up the paradigm of interculturality in theology implies exercising the charism of cultural mediation and its practical demands: capacity of translation and transit from one culture to another, a choice to enter intercultural dialogue with the resulting risks, overcoming prejudices, personal openness for the action of the Spirit in the other, scientific curiosity about differences (intercultural hermeneutics) and unconditional willingness to experience compassion and care (walking in the spirit of Christ, as the apostle Paul said: Galatians 5:15; 1 Corinthians 12.4-6). ${ }^{?}$

\section{Challenges of indigenous issues for an intercultural theology}

Dealing fairly with indigenous issues requires an effort of displacement, both personal and intellectual. This is because faced with these peoples, a large part of whom were eliminated by the 500-year history of colonization and the invasion of their territories, the main demand is to situate ourselves in the debate from the

dex.php/nepp/article/download/748/844.

8 See Franz Gmainer-Pranzl, “Teologia mundial. A responsabilidade da fé cristã na perspectiva global”, Estudos Teológicos, São Leopoldo, 52 (January-June 2012), 12-37; Boaventura de Sousa Santos, Um discurso sobre as ciências (São Paulo: Cortez, 2004).

9 See Enio R. Mueller, Teologia cristã em poucas palavras (São Paulo: Teológica; São Leopoldo: EST, 2005). 
point of view of the other. That is why there is a demand for displacement both in the sphere of personal relations and in the way of thinking. In this sense, it is worthwhile considering what Rudolf von Sinner calls hermeneutics sensitive to the other, whatever we mean by that. ${ }^{10}$ It was anthropology that taught us to consider this aspect of theological reflection in the last few decades. Currently, a major factor is the emergence of minorities in several parts of the world. In the case of the indigenous peoples in Brazil, they reached the lowest demographic level around 1950, something like 150,000 people divided into more than 200 small ethnic groups. They were more than 5 million, according to the most conservative statistics, when the Portuguese invaded the land at the beginning of the 16th century as part of a messianic project for conquest and expansion of the Iberian Peninsula. Nowadays, after an improvement in health and nutrition-which, however, are still precarious - , the struggle to demarcate the lands, the growth and advance of the indigenous movements struggling for their rights, the indigenous population has grown, reaching 810,000 people and more than 235 recognized ethnic groups, in which 180 languages are still spoken in this country. This is $0.44 \%$ of the Brazilian population. ${ }^{11}$ A novelty is the increasing emergence of urban indigenous communities with people who come to the cities seeking better living conditions.

Based on the contact with this reality, several churches and institutions develop evangelization projects and actions. In Brazil we have the presence both of conservative Christian groups and churches that usually combat specific indigenous religious references and also actions of churches that are more open to the indigenous cultures and traditions. In the field of liberation theology, the proposal for inculturation created a differential in practical action because it proposes a form of insertion that defines intercultural dialogue and solidarity as a method and requirement for a renewed evangelizing presence, breaking with the old scheme of the colonialist mission that involved conversion and breaking with the ancient traditions. ${ }^{12}$

Considering this multifaceted and challenging reality, I see a number of questions that could not be lacking in an intercultural dialogue between indigenous reality and Christian theology. Evidently it is not possible to discuss each one of

${ }^{10}$ Rudolf von Sinner, The Churches and Democracy in Brazil: Towards a Public Theology Focused on Citizenship (Eugene, Or.: Wipf \& Stock, 2012), 328f.: “...respect to otherness, the acknowledgment of difference and the right to be different is essential... A sensitive hermeneutics of the other is necessary to preserve each person's uniqueness and her right to difference, including religious difference."

11 Marta Maria Azevedo, "Diagnóstico da população indígena no Brasil", Ciência e cultura, São Paulo, 60/4 (October 2008), 19-22. Available at: http://cienciaecultura.bvs.br/pdf/cic/v60n4/ a10v60n.4.pdf. Access on: January 2, 2012.

12 See Paulo Suess, Evangelizar a partir dos projetos históricos dos outros. Ensaios de missiologia (São Paulo: Paulus, 1995), 184ff; Zwetsch, Missão como com-paixão, 335-349. 
them with all its theoretical and practical implications. Here I limit myself to raising them to facilitate new reflections in the future.

\subsection{The issue of rights: land is life!}

At least in the last 40 years the indigenous struggles have been growing throughout Latin America, as the expression of a historical turnaround: the slow but essential overcoming of colonial and subordination relations, and a time of struggle for rights and for citizenship within the new nations that were formed in the region after the independence struggles in the 19th century.

As to the indigenous peoples in Brazil, a significant fact that must be highlighted is that, beginning in the 1950s, there was a turnaround in the indigenous demographics. Until then the population had always been diminishing, since the first contacts with the Portuguese. These were responsible for the extinction of hundreds of peoples, cultures and indigenous languages in Brazil. But very timid measures taken to preserve the indigenous territories, to ensure life through more effective health actions, improvement of nutrition and the commitment of the State to guarantee the fundamental rights such as the land and the preservation of languages helped stanch the death of these peoples. The indigenous movement became a protagonist again, helped by major changes in the way some Christian churches saw their missionary task (Second Vatican Council, the WCC's Program to Combat Racism, the pastoral of interaction, liberation theology, inculturation theology) and also effective actions by sectors of civil society and universities in the advocacy of the indigenous peoples. ${ }^{13}$

It was this more favorable situation that allowed us to reach the 2010 Census in Brazil with an indigenous population of 810,000 people, as stated above. This is important not only because of the quantitative aspect. The renewal of indigenous demography raises the issue of the struggle for rights to a full life, such as land, health, education, a unique citizenship, cultural and ethnic diversity as a value and wealth for the country.

The struggle for indigenous land is historical in Brazil. The indigenous peoples never resigned themselves to the invasion and loss of their territories. Throughout the colonial period there were struggles of resistance by the peoples of the land. Even defeated and expelled, they continued to find strategies to survive, sometimes hiding behind an indistinct caboclo (mestizo) identity, although they preserved their ways of living and understanding the world that contemporaneously have allowed them to take back territories and rights that had been long denied them.

${ }_{13}$ To see church documents that are important for the period mentioned, see Paulo Suess, Em defesa dos povos indígenas. Documentos e legislação (São Paulo: Loyola, 1980). 
Since the 1970s the Statute of Indigenous Peoples (1973) voted by the National Congress was used as an instrument and legal framework to reinforce indigenous struggles and the demand for the demarcation of lands and territories that had traditionally been inhabited by them. The national development project has always ignored these rights. Currently, in National Congress, a new Statute of Indigenous Societies is awaiting a vote, and does not get any further because of sectors connected to the large landowners, controlled by agribusiness. The same government that is supposed to protect the peoples and the lands invades those spaces to run roads through them, build large hydropower plants, or even authorizes mining companies to dig the subsoil to search for minerals and natural resources for the processing industries.

This legislation was reaffirmed in the Federal Constitution of 1988 which explicitly defined, in articles 231 and 232, the fundamental rights of indigenous peoples in Brazil. By a constitutional definition, according to article 231, the indigenous people

shall have their social organization, customs, languages, creeds and traditions recognized, as well as their original rights to the lands they traditionally occupy, it being incumbent upon the Union to demarcate them, protect and ensure respect for all of their property. ${ }^{14}$

This form of acknowledging rights is very important in the case of indigenous peoples and also of the quilombola communities (originating in the free territories of enslaved black people). This means that indigenous or quilombola lands cannot be the subject of business, sale and purchase, and are out of the market for lands and territories, establishing a real historical and legal contrast to the capitalist regime which transformed the land into an economic resource and merchandise or commodity. This means that the indigenous territories are collective forms of organizing life, culture and the future of these population groups. That is why we see the permanent dispute in national society to undermine this right, through parliamentary or legal manoeuvres, social pressure by large, medium or small landowners who always use the economic factor and the right originating in production against the indigenous way of relating to and interacting with the land.

Theologically, today there is a discussion on the indigenous concept of good living as an alternative to thinking about life in this world. The concept of good living or living well (suma kawsay or suma qamaña, in Spanish buen vivir) comes from an Andean philosophy. With this concept those people tried to express

${ }_{14}$ For a discussion on legislation about indigenous peoples in Brazil, see Manuela Carneiro da Cunha, Os direitos do índio. Ensaios e documentos (São Paulo: Brasiliense, 1987). 
a life in fullness, which includes humankind and divine creation. ${ }^{15}$ At a time when crucial issues of preserving the environment affect vast regions of Brazil, Africa and Asia, above all in areas with an intense human presence and economic and energy production projects, the indigenous view obliges, at the least, to rethink the values of modern civilization and its prospects for the future. It is known that Planet Earth is limited in terms of natural and environmental resources. But the system of merchandise production that dominates the world today does not acknowledge limits and imposes itself as the only way for peoples and nations. As contemporary theologians write, looking at the one-dimensional view of the empire (which is not confounded with a nation, but concerns a way of domination), we must urgently find new ways of living, producing and imagining the future of life on earth ${ }^{16}$. This means that we urgently need a new imaginary that will allow us to define steps and strategies to struggle for the transformation of this world.

In my opinion listening to the clamour of indigenous voices and considering their ways of living and being is part of this search. For the indigenous peoples, land is life, which means to affirm the need to overcome the Western way of reducing land to a mere production input, as though the land had no history and rights.

Acknowledging these limits, however, does not concern only economic or environmental issues, but it also extends to the different ways of understanding the world, life and cultures. As Jung Mo Sung writes:

Acknowledging the limits ... based on the suffering of the poorest and most oppressed, of the excluded from the system of domination, is a central issue in the elaboration of a transcendental imagination and critical and humanizing utopia. Because, whereas the Empire tries to silence the clamor of the poorest and most oppressed ..., it is precisely this clamor that breaks with the imposed unanimity, questions the conscience of those integrated in the system and opens up breaches for what is new. ${ }^{17}$

In this sense, the struggle for indigenous rights becomes a challenge for the theology and faith of the Christian churches and communities, precisely because, when they become allied with these peoples, they are breaking with a unilateral view of the world and history and instituting signs of the utopia of another possible world,

${ }^{15}$ Cledes Markus, Renate Gierus (eds.), 0 bem viver na criação (São Leopoldo: Oikos, EST, COMIN, FLD, IECLB, 2013).

${ }^{16}$ Cf. Néstor Míguez, Joerg Rieger and Jung Mo Sung, Para além do espírito do império. Novas perspectivas em política e religião (São Paulo: Paulinas, 2012). In English under the title: Beyond the Spirit of Empire: Reclaiming liberation theology. Theology and politics in a new key. (London: SCM Press, 2009.)

17 Míguez, Rieger and Mo Sung, Para além do espírito do império, 188-189. 
in which indigenous peoples, quilombolas, marginal population groups and the environment also have the right to exist according to their world view and projects for the future.

\subsection{Resistance to colonial catechesis: Against the idea of tabula rasa}

One of the ways Christian missionaries traditionally found to integrate the indigenous peoples into the colonial system was the Christian catechesis. And the latter was considered not a way to challenge the indigenous peoples to reflect on the contents of faith, but an instrument to dominate or colonize the minds, hearts and imaginations of indigenous people. Therefore, and above all due to the resistance of the adults, the Jesuits and other missionaries always privileged the catechesis of children, since they believed that in this way they could form a new Christian people that assimilated the Christian credo at a very early age.

In 1556/57 Jesuit Manuel da Nóbrega wrote a text that clearly exposes this idea. It is the Dialogue on the conversion of the pagans, which is considered the first literary text written in Portuguese in Brazil. The text presents a dialogue between a priest and a religious of the Society of Jesus about the real chances that a pagan person would become Christian. At a certain point Father Gonçalo Alvarez states that maybe the entire effort of the Jesuits has been in vain, at least until "this pagan is not strongly subjugated and takes the faith in fear". In this writing it becomes clear what pedagogical resources were used during the colonial period to catechize indigenous people. They only would come to the faith by means of subjugation and fear. It is sad to find that this methodology continued to guide education and catechesis for centuries, and is perhaps still the motivation of many schools and churches. A consequence of this attitude was to consider the traditional indigenous religious worldview as idolatrous and subject to error. That is the reason why the missionaries fought to extirpate any remnant of indigenous practices or rituals in the missions. ${ }^{18}$

It has not been long since these missionary concepts began to be revised. They also found shelter in the Protestant missions, especially when they began to appear in Latin America during the 19th century ${ }^{19}$. Only a profound transformation of the mindset, an ecumenical and anthropological openness, respect for the other and solidarity with the indigenous peoples will allow the missionary presence among them to become beneficial and liberating. Otherwise what will remain is the raw finding that the Christian mission has allied itself to the forces of dominance and became an ideological arm of the reduction of native peoples to a spurious and ulti-

18 Zwetsch, Missão como com-paixão, 75-76.

19 Arturo Piedra, Evangelização protestante na América Latina. Análise das razões que justificaram e promoveram a expansão protestante (1830-1960) (São Leopoldo: Sinodal; Quito: CLAl, 2006), vol. 1. 
mately mistaken view of the world and of life. Fortunately there have been and there are historical examples that point to fraternal and constructive relations with the indigenous peoples, even in colonial times. One of them is the work and struggle of the Dominican Fra Bartolomeo de Las Casas, during the 16th century, who defended the indigenous rights against enslavement and destruction of those peoples and cultures over against the Spanish Empire. The text written by Las Casas in 1537, Del único modo de atraer todos los pueblos a la verdadera religión, is the testimony that not all thought and acted the same way in those days. Because he claimed that nobody can believe against their will. Therefore he condemned all wars against native peoples as unjust and tyrannical. And he also claimed that due to such a great injustice all that had been stolen from those peoples should be returned to them, something that is extremely relevant today, if we think about the forms of invasion and destruction of territories belonging to native peoples in Latin America and in Africa, for instance. According to Las Casas, there was only one true and legitimate way of attracting these peoples to the Gospel, the peaceful way. Christ himself said that the Gospel should be preached persuasively to be understood and made attractive to the will, without any violence, and this until the Day of Judgment.

Las Casas, however, was sufficiently realistic to realize that this kind of mission did not prevail, since nowhere is there a vestige of evangelical charity (or rarely, we may say, in a more mitigated manner). His conclusion is harsh and remains valid through the times: we Christians will have to render accounts on the Day of Judgment, not only of our sins, but also of damages to others caused by ourselves. This alliance between mission and colonial project was fatal to evangelization, both in Portuguese and Spanish America. Evangelization was corrupted to such an extent that one may ask whether it did in fact occur. ${ }^{20}$ This also implies that whenever the Gospel is imposed it becomes a counterfeit, an ideological imposition which, instead of liberating, enslaves, transforming a message of peace and solidarity into its opposite. These facts should not be forgotten when one seeks models of action for a new, liberating interaction with the indigenous peoples.

\subsection{Incultured liberation and interculturality: Dialogue, solidarity and interaction as a method for an intercultural theology}

It was only in the mid-20th century that the Christian churches began to rethink their understanding of mission and their missionary practices. The experience of the two great World Wars, the collapse of life for millions of people, people's disenchantment caused by the destruction meant the defeat of the optimism that the philosophy of Enlightenment and the Age of Reason had promised the world.

20 Zwetsch, Missão como com-paixão, 75. 
These facts contributed to a renewal of Christian theology, which was already being renewed by the ecumenical movement which had taken its first steps in the beginning of the century but was consolidated when the World Council of Churches was founded in 1948 in Amsterdam.

In the wake of the great changes that occurred in the Post-War world, the Second Vatican Council (1963-1965) called together by Pope John XXIII brought fresh airs to the Roman Catholic Church and inspired, in Latin America, the Bishops' Conferences of Medellín (1968) and Puebla (1979), which reaffirmed a new concept of church and Christian community, based on the centrality of the Gospel and the action of love and faith that characterizes the discipleship of Christ. The ecclesial base communities which appeared throughout Latin America when the church grassroots began to be renewed in different places experienced a new way of being Christian and living the faith. The popular reading of the Bible was a central component of this novelty. It inspired thousands of Christians to engage in struggles for social transformation in order to overcome the reigning injustice and institutionalized violence.

In this context, the proposal of a liberating mission meant a reevaluation of the presence of the churches in the Latin American reality, with profound implications for the church structures and their orthodox views. The option for the poor was a way of affirming the relevance of the Christian faith for the oppressed among all peoples and in all places, so that faith would become a central reason in the struggle for social transformation. It became clear at the time that social struggle is not an optional addition to the experience of faith, but rather a consequence of its understanding as a service of love and hope.

Recently, the evaluation of the Latin American experience by Michel Löwy, a Brazilian Marxist researcher who works at the National Center of Social Research in Paris, demonstrated that liberation Christianity was not simply an episode, ${ }^{21}$ but is rooted in the ecclesial and social experience of the Latin American people, which means that its repercussion and consequences will continue to be present and instigating for a long time, at least as long as there are poor people in this world, as Dom Pedro Casaldáliga said.

The proposal of a mission inculturated into the reality of the indigenous peoples' life went hand in hand with the practice of a liberating mission. In a way, one is complementary to the other. There was a moment in the recent course of theology in Latin America when the concept of poor had to be better specified and broadened. It had to surpass the economicist reduction and to expand so as to

${ }^{21}$ Michel Löwy, A guerra dos deuses. Religião e política na América Latina (Petrópolis: Vozes, CLACSO, LLP, 2000). 
include other groups of people, situations and cultures. That is how, faced with new questions emerging from the sociocultural reality, the proposal of an inculturation of faith, of testimony and of the very understanding of the Gospel as a liberating message was formulated. Paulo Suess, a Roman-Catholic theologian, in an analogy with the incarnation of the Son of God, defined inculturation as a process of sociocultural insertion that aims at a "radical and critical approach between Gospel and cultures". Suess adds that this approach is a presupposition for the communication of the good news of God's love in the different cultures and that two inseparable dimensions of the Christian mission are interwoven in it: goal and method, i.e. the universal of the salvation offered freely by God with the particular of the missionary presence, which always falls short of the imagined ideal. ${ }^{22}$ Inculturation is necessary and indispensable because reality is pluricultural and always challenges the limits that we impose on it based on our partial view. In the WWC documents the concept of endoculturation has been preferred as an attempt to translate the Gospel into a given culture. Anyhow, what matters here is that the dimension of the cultures became part of theological reflection as something intrinsic to the very conception of faith and its experience.

It should be reaffirmed today that liberation will not be complete as long as cultural diversity is not taken into account. This means that liberation, inculturation and cultural diversity require a view that is broadened by the concept of $i n$ terculturality, which in turn refers one to the debate on intraculturality, i.e. the experience of cultural diversity in one and the same social space that at first sight is homogeneous and univocal.

It is for this reason that the method is so crucial in intercultural dynamics. In this sense, interaction with those who are different and the learning that occurs in the practice of cultural diversity on the basis of the challenges of the everyday life of intercultural encounters have shown themselves to be the most appropriate and constructive path. Based on the experience with indigenous communities, theologian and anthropologist Lori Altmann wrote that the "pastoral of interaction is a process of missionary reeducation through which the missionary tries to place themselves in the world from the point of view of the people to whom they are committed and derives all consequences resulting from this attitude (Philippians 2:5ff)." ${ }^{23}$

This means that the search for paths of solidarity and liberation involves accepting that interculturality requires an ecumenical view on the basis of which the dialogue goes beyond Christian theology to come into creative contact with other religious traditions and experiences, in an attitude of respect and learning, without

${ }^{22}$ Suess, Evangelizar a partir..., 184.

${ }^{23}$ Lori Altmann, Convivência e solidariedade. Uma experiência pastoral entre os Kulina (Madija) (Cuiabá: GTME; São Leopoldo: COMIN, 1990), 47. 
which one cannot explore the possibilities that dialogue or mutual conversation allow one to experience. One might imagine that, in the future, there will be a conversation circle in which those who are different are welcomed and in which their right to speak and being heard is assured, so that the banquet that follows does not impose any kind of restrictions (Luke 14:15-24).

\subsection{The centrality of the community in the indigenous worldview: Reciprocity and mutual love}

In Christian theology it is uncontroversial that the church is the assembly of those who were called to the faith and to the experience of love by Christ in the Gospel. Rather than a doctrinal community, the ecclesia is the gathering of people who hear the Gospel and celebrate the presence of Christ in the sacrament of his absence, in the shared supper which is received as a living sign of his memory. Experiencing the church, the ecclesia tou theou, is a historically and culturally situated spiritual experience. This experience establishes for all people of faith a level of equality and reciprocity that, in all times, helped and instigated the churches to overcome hierarchies and divisions, challenging exclusivism and reaffirming humility and fellowship as an expression of the authenticity of Christian life (Galatians 3:28).

Now if this is true for Christian theology and the experience of faith, it should not be so difficult to understand what we learn from the indigenous peoples, namely, that the community is the center of their existence and that one can only be a human being in and with the community. Among the indigenous peoples of Latin American, Guarany theology may be the one that most splendidly shows this perception. It is known that the word is central in the Guarany worldview. The experience and theological reflection of the different Guarany groups are based on the word. A human being is a being of the word. And the word is part of divinity itself. God is word. In the Guarany view, the word existed before any other created thing. It is by the word that the world, the animals, plants and humans beings begin to exist. Human being is understood to be a being that talks, that dialogues with Our First Father. Graciela Chamorro, a theologian and historian of the Guarany, explains that, of all human faculties, speech "is the one that opens up the many pathways of communication with the divinities, since the latter are, above all, beings of 'saying well', ñe'êngatu." ${ }^{24}$

Now, the word is the raw material of community, communication and fellowship. It is through the word and through listening to the word that communicaton and fellowship are created. Human beings are a living soul, as we learn in Genesis 2:7. Human beings as living beings are beings of the word. In the Guarany view, the crea-

${ }^{24}$ Chamorro, "Religiones y culturas indígenas", 19. 
tion of the original word and the creation of the words that soon after would be the fathers and mothers of the founding words of humankind preceded the creation of the earth itself. That is why, for these indigenous sages, since the beginning human beings are a "dreamed of word-soul. The 'word-soul', $\tilde{n} e$ ', ayvu, is an embryo, a primordial constitutive element, of human beings. It is a divine and divinizing word and as such gives human beings the verticalness that distinguishes them both from their sick congeners and from the dead and the animals." ${ }^{25}$ It is a gift and cannot be the object of teaching. It is not by chance that the Guarany groups offer a certain resistance to the school in their communities. As a result of contact with the national society and as a way of appropriating knowledge that they do not have access to by other means, the Guarany accept school, but seek to imprint it with their worldview and way of being ${ }^{26}$.

Beings of the word, beings of fellowship and reciprocity, therefore. In the view of the Guarany, besides being heard, the word must be "seen". Only the person who sees the word, the person who had the direct mystical experience with the creative reality of the word and is inspired by it, has really found the path that makes them a person. This can happen in dreams or at other very special moments. But it certainly does not occur outside the community. This is possibly one of the reasons why in many Guarany communities of Mato Grosso do Sul in the last few years there has been a great number of suicides, mainly young people aged 15 to 25 years. This tragedy has been the subject of study, research and many meetings of the indigenous leaders and sages. So far there has not been a consensus about the reasons for suicide. But certainly among them the dispossession of indigenous lands, the disorganization of community life and the lack of experience of the divine word must be considered.

In this mythical and religious context, it is necessary to mention the understanding of the Guarany and other indigenous peoples about good living or the true way of being. For the Guarany this concept is connected to the word teko, which means "way of being, system, law, culture, standard, behavior, habit, condition, custom", as Bartolomeu Melià, a Jesuit who knows very much about the Guarany culture, says. In that language there are several expressions that define ways of being, including teko katu, which means the authentic and true way of being. According to Melià, teko katu is a "kind conscience that configures ... its identity, placing itself at a level of reflexive thinking ... which we might call 'philosophical'.,'27 Teko porã can be translated as "what is well". This expression is configured by a set of virtues,

${ }^{25}$ Chamorro, "Religiones y culturas indígenas", 17.

${ }^{26}$ Cf. Bartomeu Melià, "Educação guarani segundo os Guarani”, in Fontes da pedagogia latino-americana. Uma antologia, ed. by Danilo R. Streck (Belo Horizonte: Autêntica, 2010).

${ }^{27}$ Melià, “Educação guarani segundo os Guarani”, 38. 
usually social ones, but which are also expressed in personal relations. "These are above all the virtues that include reciprocity (expressed in Guarany by the affix jo, which indicates mutual relationship); teko joja (equality), teko joaybu (mutual love)." ${ }^{28}$ As regards love, it is significant that for the Guarany this word only appears as the expression of a mutual relationship. There is not, nor can there be love in a single direction. Love is a profoundly relational experience. In a selection of Guarany texts that Melia appends to the article cited, he picks out the following indigenous text that was uttered by a Guarany of the Pâi-Tavyterã group, Evangelí Morilla, of the region of Amambái in Paraguay.

You shall live well with your neighbor, with your companion; your wife you must love without anything further. Our origin is one, it does not establish differences; that is how we spread out. We must love each other, because one is Our Father who is in heaven. We cannot be each other's enemies, since we are all inhabitants of this earth of ours. When it becomes cold, we also feel cold together; it is not possible that we do not want to see each other. ...

It is best that we take the path of religion. We must pray that nothing [bad] happens to you, to live pleasantly. With this, we must illuminate our way of being. We will be again in the ancient custom. Let us be in the blessing, as we were in a beginning. During dawn one must sing (perform the ritual); that the disease does not set foot again in this land in any way, but instead keep anything useless away from you. Now people are increasingly deleting the old custom. ${ }^{29}$

This testimony is embarrassing if we think about the centuries of colonization and Christianization that forced this people and so many others to take distance from their worldviews and theology, this, when the latter were not summarily condemned. Fortunately, both in the past and in the present day, there are people who have eyes and ears for this wisdom and its implications in searching for more egalitarian, symmetrical and life-restoring relations with these peoples. Anyway, Guarany theology offers a strong example of how interculturality and the search for an intercultural theology offer the opportunity to recover central dimensions of evangelical faith and of the Gospel of Christ in the dialogue with the other. This challenge brings as a task that cannot be put off the reinterpretation of the Gospel based on the indigenous traditions and their way of being and living. It is not yet written what the future of this reinterpretation holds for us. But we can already get an intuition of it

${ }^{28}$ Melià, “Educação guarani segundo os Guarani”,. 38.

29 In Melià, "Educação guarani segundo os Guarani”, 50. 
in what in Latin America is being called Indian theology, ${ }^{30}$ which has become public since the 1990s, mainly after the First Latin American Meeting on Indigenous Theology, held in Mexico City, in September 1990. Eleazar López Hernández, a Zapotec from Mexico, Aiban Wagua, a Kuna from Panama, María Chávez (deceased), Ana María Vargas and Abraham Colque, Aymaras from Bolivia, Antonio Otzoy, a Kaqchikel Maya from Guatemala, Margarita de La Torre, an Otavalo from Ecuador, and so many other people who did and still do dedicate themselves to the dialogue between Christian theology and the indigenous theologies in solidarity and commitment to these peoples, such as Diego Irarrázaval, Graciela Chamorro, Victoria Carrasco, Miguel Ángel Miranda, Manuel Marzal, Bartomeu Melià, Paulo Suess, Walter Sass, Josef Estermann, show the depth and transcendence which await us in the encounter with these millenarian traditions and wisdoms. ${ }^{31}$

\section{Conclusion}

The project of an intercultural theology in Latin America is taking its first steps. Even so, one can already say that it will bring challenges and impulses to the Christian theologies and churches that have a great impact. The struggle for indigenous rights and for their dignity as peoples and cultures also challenges national societies and their political objectives. The simple presence of these peoples on the public scene, through marches and protests, autochthonous movements and organizations, is typically shown as if they were an obstacle to the future of our societies, when, in fact, they represent the retrieval of a prophetic dimension forgotten in theology and in the Christian communities. Their insistence on being heard, their struggle for land and territory, their worldview of a radically other world, in which nature will not only be preserved but seen as a partner of humankind, all these critical elements can serve as the trigger for a sui generis alliance with other popular movements that begin to raise their voice in Latin American and in many other places.

These movements present an extensive and not very articulated list of claims. Possibly one of their greatest weaknesses is the lack of a broad political articulation. But what we urgently need to perceive is that currently the very system that dominates the world is being challenged. It is no longer possible to remain silent

${ }^{30}$ On the understanding of diakonia and solidary action as a liberating service from the perspective of the indigenous peoples, see Margarita de La Torre and Roberto Zwetsch, Diaconía y solidaridad desde Ios pueblos indígenas (São Leopoldo: Sinodal, EST, CETELA, 2007). In the essays gathered in this book, indigenous intellectuals challenge some Christian diaconal practices and propose a profound change in these actions, considering the experiences of many indigenous communities, in which they experience caring for their life companions and the environment itself.

31 Zwetsch, "Deus na aldeia", 55-65. 
and inert when we see the commodification of life as a whole. We must urgently admit that we need an alternative thinking that reestablishes a utopian dimension of life, with the mark of sisterly-brotherly and solidary hope. And that this thinking will not just fall in our laps. It will be the result of reflection, of seeking, of struggle and of the willingness to rethink the foundations of our existence in this world, based on faith and on transforming love. As Jung Mo Sung wrote, echoing the thinking of his partners Néstor Míguez and Joerg Rieger, the utopia of a new critical and humanizing society

must come from transcendental imagination based on the sufferings, struggles and lives of poor, marginalized and/or oppressed people. That is what ensures real transcendence in relation to the dominant system and its utopia. ${ }^{32}$

Acknowledging the limits of this critical and humanizing utopia that includes the indigenous peoples, the African-American population groups and all those strata of the population excluded from the benefits of the system, the challenge for us is to hear their clamor for the right to life. It is these cries that break with the false unanimity of the system, that challenge the conscience of people of faith and of the better placed strata of society, that open breaches for the new in what seemed to be insurmountable. Perhaps thus, with modesty, but also daring, we can imagine solutions for the impasses we experience today as persons and societies.

In this critical and auspicious spirit, we can conclude with the words of Jung Mo Sung in the aforementioned text:

Solidarity, which comes from compassion for concrete people who suffer with poverty and/or the violation of their human dignity, leads us to take up with these people-in a dialogue with them-the struggle for their liberation. In this struggle there emerges the transcendental imagination of a society where all bodies satisfy their hunger and other rights and interact in friendship, respecting the diversities and plurality. This imagination is used to interpret reality and the struggle and to provide a foundation for the faith that moves us in the struggle. ${ }^{33}$

It is this contrasting, unprecedented and challenging experience that we see in our interaction with the indigenous peoples. In a way, interacting and moving on with them, dreaming of a new heaven and a new land inhabited by justice (1 Peter 3:13) and experiencing unusual dimensions of reciprocity and mutual love, is already to live-amid conflicts and contradictions — even if incompletely and

${ }^{32}$ Míguez, Rieger and Mo Sung, Para além do espírito do império, 187.

${ }^{33}$ Míguez, Rieger and Mo Sung, Para além do espírito do império, 188-189. 
provisionally but in a real, symbolical and significant manner signs of the reign of God (Luke 17:21)!

\section{References}

Altmann, Lori. Convivência e solidariedade. Uma experiência pastoral entre os Kulina (Madija). Cuiabá: GTME; São Leopoldo: Comin, 1990.

Azevedo, Marta Maria. Diagnóstico da população indígena no Brasil. In: Ciência e cultura, São Paulo, vol. 60, $\mathrm{n}^{\circ}$ 4, p. 19-22, out 2008: <http://cienciaecultura.bvs.br/pdf/cic/ v60n4/a10v60n4.pdf>, acessado em 02/01/2012.

Carrasco, Victoria. Espiritualidad y fe de los pueblos indígenas. Ensayos. Quito: INPPI, 1995.

Cavalcante, Ronaldo; Sinner, Rudolf von. Teologia pública. Em debate. V. 1. São Leopoldo: Sinodal, EST, 2011.

Chamorro, Graciela. A espiritualidade Guarani: uma teologia ameríndia da palavra. São Leopoldo: Sinodal, IEPG-EST, 1998.

Chamorro, Graciela. Terra madura. Yvy Araguyje: fundamento da palavra guarani. Dourados: Ed. da UFGD, 2008.

Colque, Abraham; Estermann, Josef (Coords). Movimientos sociales y teología en América Latina. La Paz: ISEAT, 2010.

Cunha, Manuela Carneiro da. Os direitos do índio: ensaios e documentos. São Paulo: Brasiliense, 1987.

De La Torre, Margarita; Zwetsch, Roberto. Diaconía y solidaridad desde los pueblos indígenas. São Leopoldo: Sinodal, Est, Cetela, 2007 (Série Diaconia na América Latina, vol. 5).

Estermann, Josef. Interculturalidad: vivir la diversidad. La Paz: ISEAT, 2010.

Fornet-Betancourt, Raúl. Interculturalidade: crítica, diálogo e perspectivas. São Leopoldo: Nova Harmonia, 2004.

Gmainer-Pranzl, Franz. Teologia mundial. A responsabilidade da fé cristã na perspectiva global. Estudos Teológicos. São Leopoldo, v. 52, p. 12-37, já-jul. 2012.

Irarrázaval, Diego. De baixo e de dentro. Crenças latino-americanas. Trad. Leszek Lech. São Bernardo do Campo: Nhanduti, 2007.

Jacobsen, Eneida; Sinner, Rudolf von; Zwetsch, Roberto E. Teologia Pública. Desafios sociais e culturais. V. 2. São Leopoldo: Sinodal, EST, 2012.

Löwy, Michel. A guerra dos deuses. Religião e política na América Latina. Trad. Vera Lúcia M. Joscelyne. Petrópolis: Vozes, CLACSO, LLP, 2000.

Mamani, Fernando Huanacuni. Vivir bien/Buen vivir. Filosofía, políticas, estrategias y experiencias regionales. La Paz: Convenio Andrés Bello; Instituto Internacional de Integración, 2010.

Markus, Cledes; Gierus, Renate (Orgs.). O bem viver na criação. São Leopoldo: Oikos, COMIN, EST, FLD, IECLB, 2013.

Marzal, Manuel M. et alii. 0 rosto índio de Deus. Petrópolis: Vozes, 1989.

Melià, Bartomeu. Educação guarani segundo os Guarani. In: Streck, Danilo R. (Org.). Fontes da pedagogia latino-americana. Uma antologia. Belo Horizonte: Autêntica, 2010, p. 38. 
Míguez, Néstor ; Rieger, Joerg ; Mo Sung, Jung. Para além do espírito do império. Novas perspectivas em política e religião. São Paulo: Paulinas, 2012.

Mueller, Enio R. Teologia cristã em poucas palavras. São Paulo: Teológica; São Leopoldo: EST, 2005.

Fe y pueblo. La Paz: Iseat, nº 17, p. 4-39, Julio 2010.

Piedra, Arturo. Evangelização protestante na América Latina. Análise das razões que justificaram e promoveram a expansão protestante (1830-1960). V. 1. Trad. Roseli Schrader Giese. São Leopoldo: Sinodal; Quito: CLAI, 2006.

Ricardo, Beto; Ricardo, Fanny (Eds.). Povos indígenas no Brasil: 2006-2010. São Paulo: Instituto Socioambiental, 2011.

Santos, Boaventura de Sousa. Um discurso sobre as ciências. São Paulo: Cortez, 2004.

Santos, Ricardo Ventura; Pereira, Nilza de Oliveira Martins. Os indígenas nos censos nacionais no Brasil. In: Cadernos de Saúde Pública. Rio de Janeiro, 21(6), p. 1626-1627, nov-dez 2005, cf.: <www.scielo.br/pdf/csp/v21n6/01.pdf>, acessado em 02/01/2012.

Sass, Walter. 0 Deus trinitário está presente antes da chegada do missionário. In: Estudos Teológicos. São Leopoldo, v. 44, n. 2, p. 73-81, 2004.

Suess, Paulo. Causa indígena e Fórum Social Mundial 2003. In: Revista Eclesiástica Brasileira, Petrópolis, vol. 63, n.251, p. 699-703, julho 2003.

Suess, Paulo. CIMI 30 anos - Contexto, origem, inspiração. In: Revista Eclesiástica Brasileira, Petrópolis, v. 63, n. 250, p. 436-442, abril 2003.

Suess, Paulo. Em defesa dos povos indígenas. Documentos e legislação. São Paulo: Loyola, 1980.

Suess, Paulo. Evangelizar a partir dos projetos históricos dos outros. Ensaios de missiologia. São Paulo: Paulus, 1995.

Susin, Luiz Carlos; SANTOS, Joe Marçal G. dos. Nosso planeta. Nossa vida. Ecologia e teologia. São Paulo: Paulinas, 2011.

Zwetsch, Roberto E. "Deus na aldeia". A relação entre protagonismo indígena, ação missionária de igrejas cristãs e outros agentes em comunidades indígenas. In: LANGER, Protasio Paulo; Chamorro, Graciela (Orgs.). Missões, militância indigenista e protagonismo indígena. Dourados: UFGD; São Bernardo do Campo: Nhanduti, 2012, p. 39-55.

Zwetsch, Roberto E. Missão como com-paixão. Por uma teologia da missão em perspectiva latino-americana. São Leopoldo: Sinodal, EST; Quito: CLAI, 2008.

Zwetsch, Roberto E. Teologias da libertação e interculturalidade: aproximações e avaliação crítica. In: Protestantismo em Revista. São Leopoldo, vol. 30, p. 32-49, jun-abr. 2013 (www.faculdades est/biblioteca/portal periodicos) 